\title{
Karakteristik Metode Sift dalam Aplikasi Sistem Pengenalan Motif Batik
}

\author{
MILDA GUSTIANA HUSADA, DINA BUDHI UTAMI, IWAN ZAR \\ Program Studi Informatika, Institut Teknologi Nasional Bandung
}

Email: mghusada@itenas.ac.id

Received 12 September 2019 | Revised 5 Oktober 2019 | Accepted 26 Oktober 2019

\begin{abstract}
ABSTRAK
Pada kajian ini dibahas penerapan CBIR yaitu cara perolehan temu balik (retreival) objek citra melalui proses pembandingan antara citra uji terhadap citra latih yang dikumpulkan dalam suatu database. Proses membandingan citra berlandaskan pada tanda-tanda (ciri) yang dimiliki diantara citra tersebut. Tandatanda yang digunakan pada cara CBIR yaitu berdasarkan kemiripan warna, bentuk, dan tekstur. Pada makalah ini metode SIFT digunakan untuk mendapatkan dan mendeskripsikan fitur-fitur lokal yang ada pada citra. Fitur citra latih dan citra uji yang diperoleh kemudian dibandingkan dengan menggunakan Nearest Neighbour Search untuk memperoleh tingkat kemiripan (proses image matching). Pengujian dilakukan pada citra yang diperoleh melalui kamera dan citra yang sudah berupa data digital. Berdasarkan pengujian, nilai precision dan recall untuk citra uji yang diambil melalui kamera berturut-turut adalah $64 \%$ dan 12,8\%, sedangkan untuk citra uji dari digital dioleh adalah $84 \%$ dan $16.8 \%$.
\end{abstract}

Kata kunci: CBIR, SIFT, Image Matching, Nearest Neighbor Search

\begin{abstract}
This study discusses the application of CBIR, which is a way to retrieve objects in the form of image, by comparing tested-images-against training images whice are collected in a database. Comparison of images is based on the characteristic information in the image. CBIR method is used for searching process based on the similarity of colors, shapes, and textures. In this paper the SIFT method is applied to obtain and describe local characteristics of the images. The obtained features of trainied-image and image query are compared to provide similarity by using Nearest Neighbor Search. Tests are carried out on images that obtained through cameras and images that have been in the form of digital data previously, which known as image matching process. Based on the testing, the precision and recall values for test images that taken through cameras are $64 \%$ and $12.8 \%$ respectively, while for digital test images obtained are $84 \%$ and $16.8 \%$.
\end{abstract}

Keywords: CBIR, SIFT, Image Matching, Nearest Neighbor Search 


\section{1. PENDAHULUAN}

Pada era komputer seperti saat ini, pengenalan (recognition) merupakan bidang penelitian yang menjadi sorotan. Pada umumnya objek pengenalan berkaitan dengan tulisan (teks) dan citra. Sejumlah penelitian telah menghasilkan publikasi berkenaan pengenalan objek menggunakan bantuan komputer untuk proses temu kembali (retreiva). Kajian temu kembali meliputi objek tulisan (text-document retreival) dan citra (image retreival) (Setiyawan, 2013)(Pratama, 2014)(Agustin, 2013)(Putri, 2015).

Batik adalah hasil cipta masyarakat Indonesia berupa kain yang bercorak khas yang mana pada masa kini menjadi makin lebih populer. Batik, baik proses pembuatan maupun corak yang dimiliki setiap daerah adalah menjadi bagian warisan yang wajb dilestarikan. Namun demikian beragamnya motif batik membuat masyarakat sulit untuk mengenalinya satupersatu. Hal lainnya adalah kemiripan antara satu motif batik dan motif batik lainnya dengan ragam hias dan pola yang hampir serupa juga membuat masyarakat sulit untuk membedakan. Informasi batik dapat diperoleh melalui katalog, berkunjung ke musium atau galeri batik maupun kepada para seniman batik. Untuk mendapatkan informasi secara praktis, aplikasi pencarian kemiripan antar motif batik menjadi sasaran penelitian ini. Era teknologi saat ini, terutama berkaitan dengan teknik pemrosesan citra (image processing), sangat menunjang untuk membentuk sistem pengenalan kemiripan antar motif batik. Teknik Content Based Image Retrieval merupakan bidang Computer Vision (CV) dan digunakan untuk melakukan pencarian kemiripan bentuk motif batik, dimana metode Scale Invarian Feature Transform (SIFT) digunakan sebagai teknik perolehan fitur pada aplikasi yang dibangun.

Proses perancangan maupun pembuatan aplikasi menjadi bagian untuk mewujudkan sarana bantu bagi pengguna dalam hal pencarian kemiripan bentuk motif batik. Disamping hal tersebut, hal penting lainnya adalah bagaimana menerapkan teknik Content Based Image Retrieval dengan menggunakan metode SIFT sebagai teknik perolehan fitur suatu motif batik. Pada pengkajian ini beberapa hal menjadi ruang lingkup berkaitan dengan aplikasi yang dibentuk. Citra baik sebagai citra pada proses pelatihan maupun pada proses pencarian (cirra uji) memuat tidak lebih dari satu motif batik. Motif batik yang digunakan citra latih memiliki ukuran 300 × 300 piksel. Pada proses pencarian kemiripan antar motif batik, hasil yang diperoleh adalah 10 citra dengan kemiripan terbaik. Pada kajian ini motif batik yang digunakan adalah motif kawung, motif nitik, dan motif parang. Dalam hal pengujian, citra uji yang digunakan adalah citra motif batik yang tersimpan dalam kumpulan citra (database), dan, citra motif batik yang langsung diperoleh melalui kamera.

\section{INFORMASI LINGKUP KAJIAN}

\subsection{Batik}

Batik merupakan hasil budaya masyarakat Indonesia berupa kain bermotif yang mengandung tanda (simbol) juga muatan seni dan keindahan yang tinggi. Ciri khas pada motif batik hasil karya masyarakat Indonesia menjadi jati diri dan pembeda dengan budaya bangsa lain. Indonesia sangat bangga dengan diterimanya batik oleh UNESCO sebagai peninggalan budaya bangsa. Gambar 1 menunjukkan satu motif batik yaitu batik kawung. 


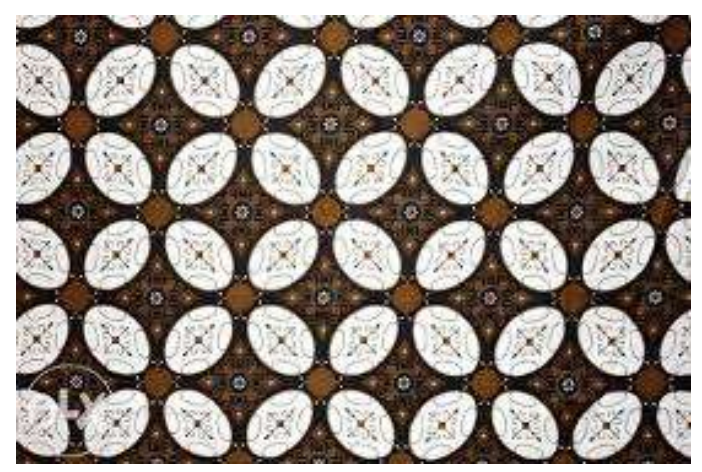

Gambar 1. Motif Batik Kawung

(Sumber https://encrypted-tbn0.gstatic.com/images?q=tbn:ANd9GcSWMEIu 816CMN9WphUWTsqRTa7VBDjnUeYGWntN6GRJsmospXeMhg\&s)

\subsection{Content Based Image Retrieval}

Konsep temu balik untuk citra dengan nama CBIR (Content Based Image Retrieval) dilakukan dengan cara membandingkan antara citra yang dicari (query) terhadap kumpulan citra yang ada di dalam database. Pembandingan dilakukan berdasarkan informasi ciri yang dikandung pada setiap citra tersebut. Parameter pencarian yang umum digunakan pada metode CBIR adalah pencarian berdasarkan kemiripan terhadap warna (color), bentuk (shape), dan komposisi (texture). Berdasarkan arsitektur sistem CBIR (Bharathi, K. 2017) yang disusun ulang, secara umum proses CBIR seperti yang ditunjukkan pada Gambar 2.

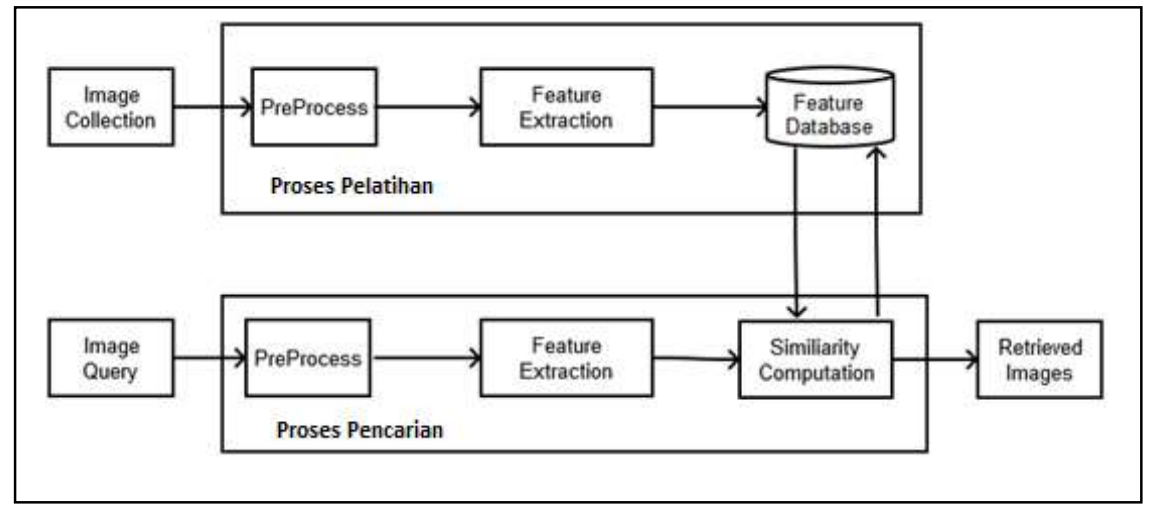

Gambar 2. Proses pada Metoda CBIR

Berdasarkan proses pengolahan data, metoda CBIR dibagi menjadi dua bagian proses. Proses pertama adalah proses pelatihan (Training) yang merupakan proses pemasukan data ciri (fitur) citra ke dalam database kumpulan citra, dan proses kedua adalah proses pencarian (searching) yang mengandung proses pengenalan (recognizing) citra berdasarkan kemiripan ciri antara citra yang diuji terhadap citra yang dilatih.

Proses yang terjadi dalam metoda CBIR, pada subproses pelatihan dan pengujian terdapat kegiatan yang sama dan yang khusus. Proses yang terjadi baik pada subproses pelatihan maupun pencarian adalah preprocessing dan feature extaction. Preprocessing merupakan proses pengolahan citra untuk mengurangi pengaruh dari berbagai macam kondisi gambar. Feature Extraction merupakan proses ekstraksi informasi low-level pada citra yang pada umumnya berdasarkan warna, sisi, tekstur, dan bentuk. 
Pada subproses pelatihan, setelah ciri citra yang diperoleh melalui feature extraction maka ciri tersebut disimpan di dalam database kumpulan ciri. Database dari kumpulan ciri ini digunakan sebagai pembanding untuk operasi image matching di dalam proses similarity computation yang ada pada proses pencarian (retrieval). Hasil kemiripan citra yang diperoleh (retreived images) maka dilakukan proses pemeringkatan terhadap citra yang memiliki kemiripan (relevant) terhadap citra query. Dalam kajian ini keluaran dari proses pemeringkatan citra adalah memunculkan sejumlah citra yang memiliki kemiripan tersebut.

\subsection{Scale-invariant feature transform}

Dalam teknologi computer vision, dikenal algoritma untuk melakukan proses pendeteksian dan penafsiran fitur-fitur lokal yang ada pada citra, yaitu algoritma Scale-Invariant Feature Transform (SIFT). Keypoint descriptor suatu citra adalah yang dihasilkan oleh proses SIFT. Kemiripan antara dua buah citra diperoleh dengan membandingkan keypoint descriptor masing-masing citra tersebut. Proses-proses secara umum yang dilalui untuk menghasilkan keypoint descriptor dari SIFT terdiri atas empat tahapan utama yang diproses secara berurutan. Empat tahapan tersebut adalah (1) Scale-Space Extrema Detection, (2) Keypoint Localization, (3) Orientation Assignment dan (4) Keypoint descriptor (Lowe, 2004)(Almeida, 2009). Urutan proses tersebut ditampilkan oleh Gambar 3.

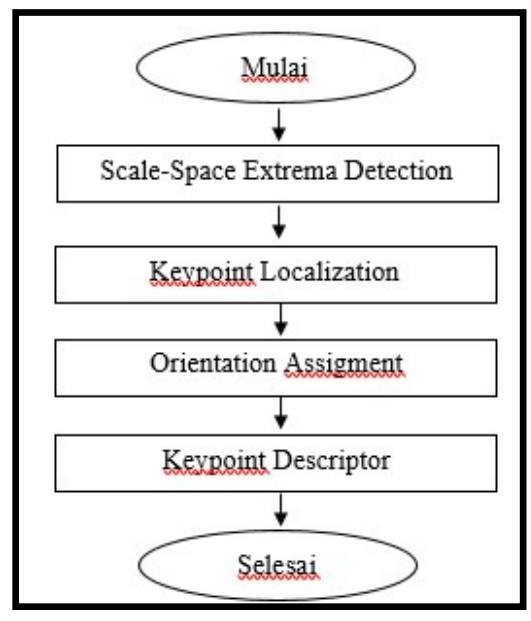

Gambar 3. Flowchart scale-invariant feature transform

Proses Scale-Space Extrema Detection melakukan proses pendeteksian lokasi pada citra yang akan digunakan sebagai sumber perolehan untuk calon keypoint dan akan diproses pada tahapan berikutnya. Proses mencari calon keypoint yang sesuai dilaksanakan dengan cara menentukan lokasi pada citra yang memiliki sifat invariant dengan perubahan skala. Pada proses Keypoint Localization dilakukan penghilangan (eliminasi) keypoint yang berciri tingkat kontras yang rendah, peka terhadap derau (noise) dan terdapat di sepanjang sisi. Tahap berikutnya adalah tahap Orientation Assignment yang menghasilkan informasi keypoint berupa lokasi pada citra dan skala. Pemberikan orientasi yang konsisten pada setiap keypoint maka deskriptor SIFT dapat direpresentasikan relatif terhadap orientasi tersebut sehingga hasil yang diperoleh menjadi tahan terhadap operasi rotasi pada citra. Tahap akhir adalah proses untuk memperoleh Keypoint Descriptor dimana gradien citra dihitung dan dipilih disekitar skala pada keypoint untuk direpresentasikan sebagai deskriptor SIFT. Keypoint Descriptor yang dihasilkan bersifat tahan terhadap perubahan bentuk pada citra dan sedikit perubahan illuminasi. 


\subsection{Precision dan Recall}

Karakteristik penilaian untuk ketepatan (accuration) sistem temu kembali (retreival) atas pengenalan objek dinilai dari sisi ketelitian (precision) dan jumlah perolehan (recall). (Deselaers, T.2007) (Lestari, 2016). Precision merupakan perbandingan jumlah total citra relevan yang didapatkan melalui sistem terhadap jumlah seluruh citra yang diambil oleh sistem tersebut baik citra yang relevan ataupun yang tidak.

$$
\text { Precision }=\frac{\text { jumlah objek relevan yang terambil }}{\text { Jumlah objek yang terambil }} \times 100 \%
$$

Recall merupakan perbandingan jumlah total citra relevan yang didapatkan oleh sistem dengan jumlah seluruh citra yang ada pada koleksi citra baik citra tersebut terambil oleh sistem maupun tidak.

$$
\text { Recall }=\frac{\text { Jumlah objek relevan yang terambil }}{\text { Jumlah objek relevan yang ada dalam database }} \times 100 \%
$$

Kedua karakteristik penilaian ini digunakan dalam pengujian aplikasi sistem pengenalan yang dibangun.

\section{RANCANG BANGUN APLIKASI}

\subsection{Perancangan aplikasi}

Pada bagian ini dipaparkan mengenai alur proses perancangan dari aplikasi sistem pencarian kemiripan bentuk motif batik dengan menerapkan metode SIFT. Adapun proses yang dilakukan diperlihatkan oleh Gambar 3.

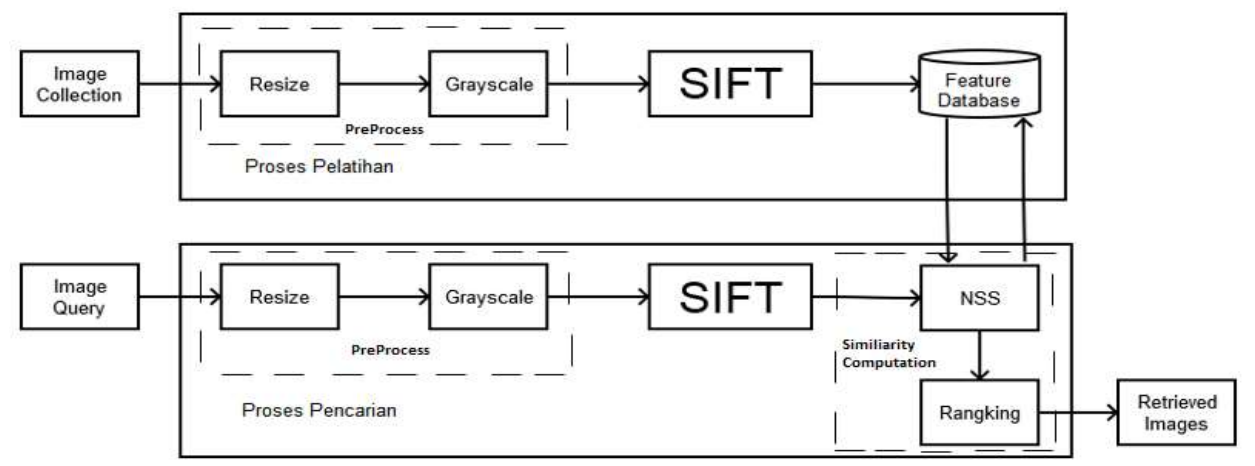

Gambar 3. Diagram Blok Aplikasi Sistem Pengenalan Motif Batik

Aplikasi sistem pengenalan motif batik pada Gambar 3 memiliki dasar proses yang selaras dengan proses ditunjukkan oleh Gambar 2 sebelumnya. Image Collection merupakan kumpulan data citra sebagai data latih yang akan diperoleh ekstraksi fiturnya. Image Query adalah citra yang akan diuji kemiripannya dimana data ini diperoleh dari citra yang diambil melalui kamera maupun yang sudah dimiliki. Preprocessing yang dilakukan kepada citra yang digunakan, menjalankan proses resize dan greyscalling. Langkah selanjutnya adalah proses perolehan fitur citra, baik citra latih maupun citra uji, yang diekstraksi menggunakan algoritma SIFT. Untuk perolehan fitur dari citra latih maka fitur disimpan dalam database. Dalam proses pengenalan, fitur citra uji (image query) akan diekstraksi menggunakan 
algoritma SIFT, yang kemudian akan dibandingkan kemiripannya dengan fitur pada database. Proses perhitungan kemiripan fitur descriptor yang digunakan adalah Nearest Neighbour Search (NSS). Proses pemeringkatan (ranking) terhadap gambar diperoleh berdasarkan nilai dari proses pencocokan kesamaan (similarity matching). Nilai pemeringkatan yang dihasilkan kemudian ditampilkan sebagai keluaran aplikasi yaitu berdasarkan urutan kemiripan citra uji dengan citra latih pada database.

\subsection{Pembangunan aplikasi}

Aplikasi terdiri atas empat pilihan utama yaitu (1) pilihan untuk proses pencarian dan pengenalan motif batik yaitu dengan mengisikan masukan citra uji berdasarkan citra yang sudah disiapkan, (2) pilihan untuk proses pencarian melalui kamera yang bertujuan untuk memasukkan citra uji (image query) secara langsung melalui kamera PC, (3) pilihan untuk proses pelatihan untuk memperoleh ekstraksi fitur dari data citra motif batik sebagai citra latih, dan (4) pilihan untuk menutup aplikasi pencarian kemiripan bentuk motif batik.

Gambar 5 memperlihatkan tampilan awal untuk proses pencarian dan pengenalan citra motif batik yang diperoleh melalui kamera PC. Pilihan masukan citra motif batik dilengkapi dengan pilihan yang berfungsi sebagai tipe video dan resolusi.

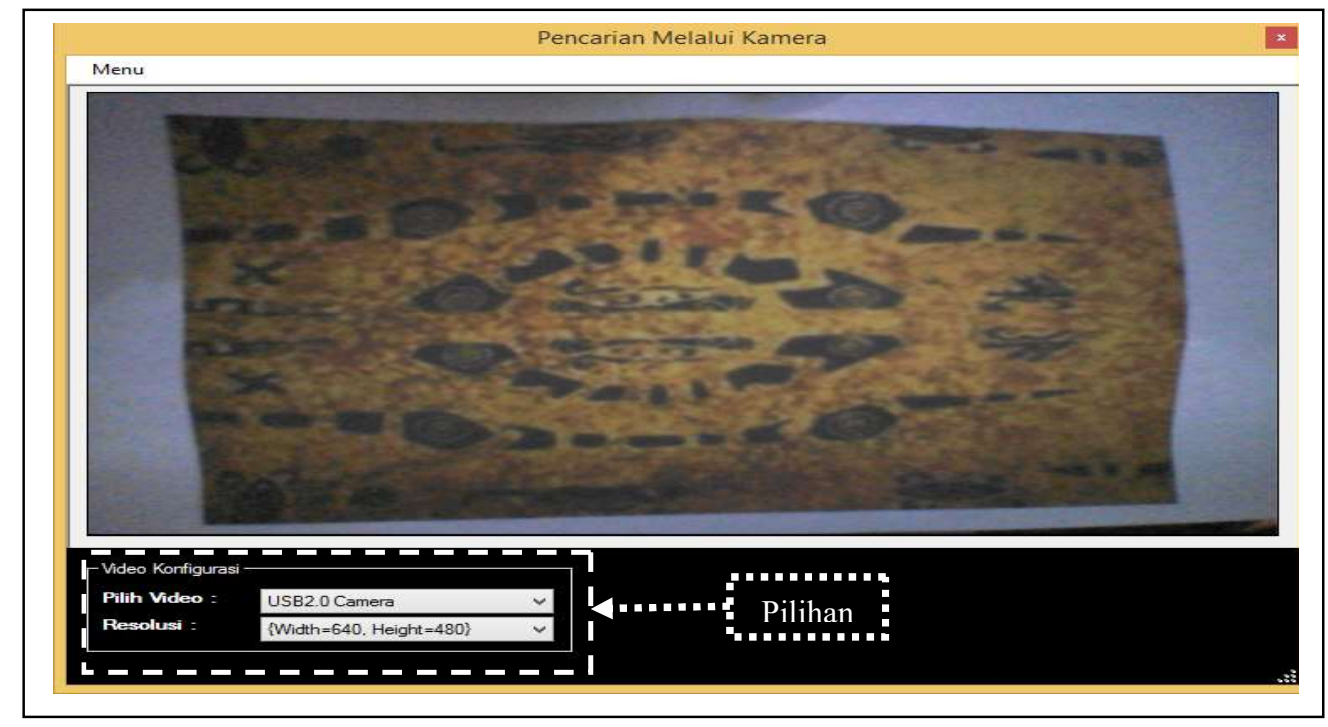

Gambar 5. Tampilan Pilihan Masukan Citra Uji Melalui Kamera

\subsection{Proses menu Pencarian Motif Batik}

Pencarian motif batik dalam aplikasi berbasis CBIR ini dilakukan untuk memperoleh motif batik dengan tingkat kemiripan terdekat sebanyak 10 citra motif batik. Untuk proses pencarian motif batik dengan sumber data citra berupa berkas citra digital yang tersedia dalam suatu direktori, maka yang dilakukan adalah menjalankan menu pilihan Pencarian Motif Batik yang tampil pada menu awal. Keluaran yang ditampilkan adalah form keberadaan data seperti pada Gambar 6. Pada paparan ini, sebagai contoh proses pemilihan dan pengenalan, citra motif batik yang dipilih adalah motif batik ciptoning.

Hasil proses pengenalan yang dijalankan, diperoleh sepuluh citra motif batik yang memenuhi tingkat kemiripan. Gambar 7 memperlihatkan empat dari sepuluh motif batik dengan prosentase tingkat kemiripan yang dekat yaitu berturut-turut dari peringkat terbesar sampai terkecil adalah 99,82\%, 99,19\%, 99,18\% dan 99,15\%. 


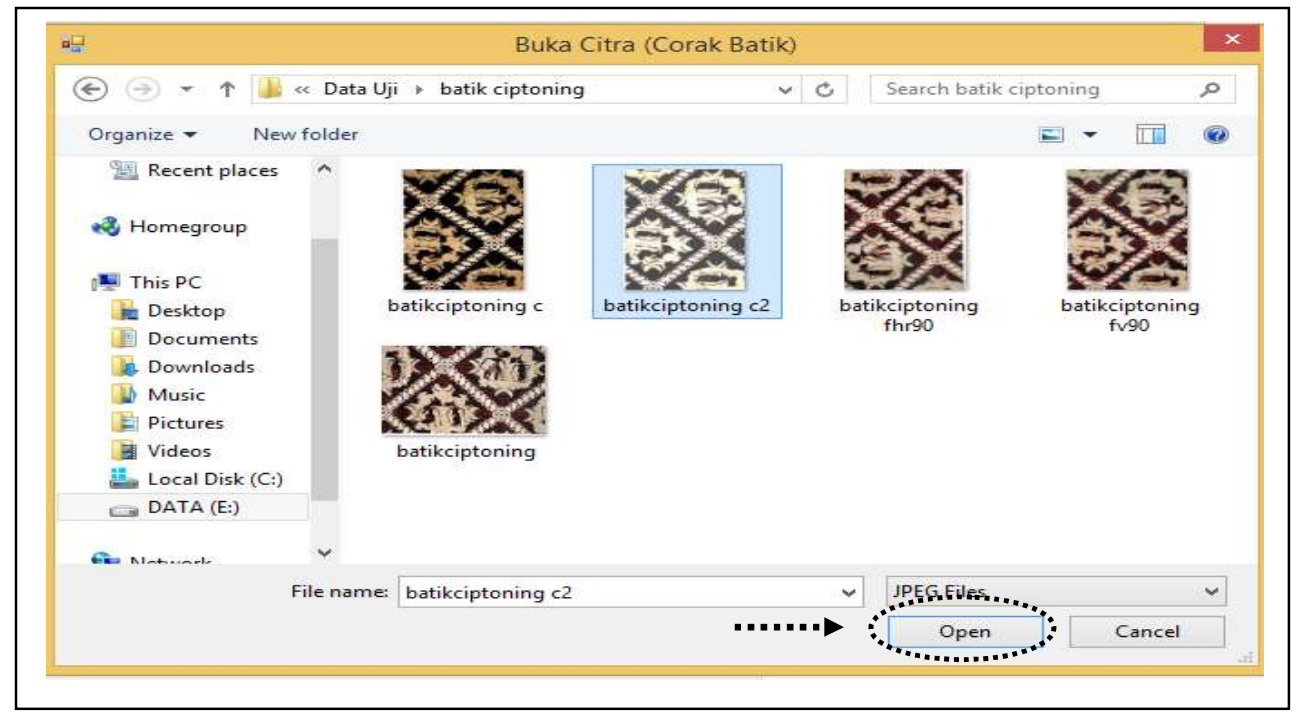

Gambar 6. Tampilan Aplikasi untuk Memilih Data Citra Motif Batik yang akan Diuji

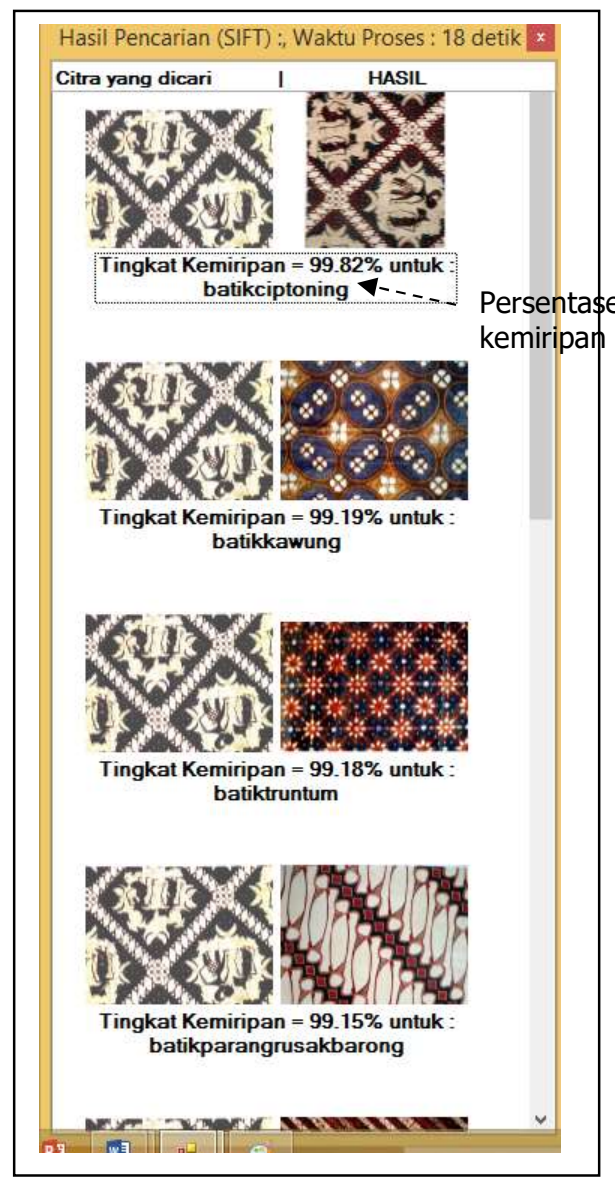

Gambar 7. Tampilan Aplikasi untuk Perolehan 4 Hasil Pencarian dari 10 


\subsection{Pengujian proses pencarian}

Pengujian proses pencarian dan pengenalan citra dijalankan dengan dua cara yaitu menggunakan citra yang diperoleh melalui kamera, dan, menggunakan citra uji dalam bentuk berkas citra yang tersimpan. Pengujian aplikasi dilakukan sebanyak 5 kali dari setiap jenis batik dimana jumlah batik adalah sebanyak 25 jenis sehingga jumlah keseluruhan pengujian adalah 125. Karakteristik kemiripan yang digunakan adalah menggunakan persentase precison dan recallyang dinyatakan berturut-turut oleh Persamaan (1) dan (2).

\subsubsection{Pengujian Melalui Kamera}

Pengujian citra yang dilakukan melalui kamera menggunakan satu motif citra batik yang akan diuji. Citra motif batik yang diuji diperoleh melalui kamera sebanyak 5 kali dengan orientasi yang berbeda-beda. Hasil pengujian citra motif batik melalui kamera dapat dilihat pada Tabel 1.

Tabel 1. Hasil Pengujian Citra Motif Batik Melaui Kamera

\begin{tabular}{|c|c|c|c|}
\hline No & Citra Batik (Data Uji) & Hasil & Kemiripan Motif Batik \\
\hline 1 & Batik Ciptoning & 4 dari 5 mirip & Motif Kawung \\
\hline 2 & Batik Jogja & 4 dari 5 mirip & Motif Kawung \\
\hline 3 & Batik Tulis Madura & 2 dari 5 mirip & Motif Kawung \\
\hline 4 & Batik Truntum & 3 dari 5 mirip & Motif Nitik \\
\hline 5 & Batik Tiga Negeri & 5 dari 5 mirip & Motif Kawung \\
\hline 6 & Batik Tambal & 4 dari 5 mirip & Motif Kawung \\
\hline 7 & Batik Sulawesi Tengah & 5 dari 5 mirip & Morif Kawung \\
\hline 8 & Batik Sidomukti & 3 dari 5 mirip & Motif Nitik \\
\hline 9 & Batik Semarang Motif Tugu & 0 dari 5 mirip & Motif Nitik \\
\hline 10 & Batik Semarang & 1 dari 5 mirip & Motif Nitik \\
\hline 11 & Batik Sawat & 5 dari 5 mirip & Motif Nitik \\
\hline 12 & Batik Pekalongan & 0 dari 5 mirip & Motif Nitik \\
\hline 13 & Batik Parang Rusak Barong & 3 dari 5 mirip & Motif Parang \\
\hline 14 & Batik Parang Kusumo & 1 dari 5 mirip & Motif Parang \\
\hline 15 & Batik Papua & 0 dari 5 mirip & Motif Parang \\
\hline 16 & Batik Nitik Karawitan & 5 dari 5 mirip & Motif Nitik \\
\hline 17 & Batik Melayu Tamban & 1 dari 5 mirip & Motif Parang \\
\hline 18 & Batik Melayu Keranggong & 1 dari 5 mirip & Motif Parang \\
\hline 19 & Batik Madura & 1 dari 5 mirip & Motif Parang \\
\hline 20 & Batik Liris & 5 dari 5 mirip & Motif Parang \\
\hline 21 & Batik Kawung & 4 dari 5 mirip & Motif Kawung \\
\hline 22 & Batik Indonesia & 4 dari 5 mirip & Motif Parang \\
\hline 23 & Batik Gurda & 5 dari 5 mirip & Motif Nitik \\
\hline 24 & Batik Grompol & 4 dari 5 mirip & Motif Nitik \\
\hline 25 & Batik Cuwiri & 3 dari 5 mirip & Motif Kawung \\
\hline
\end{tabular}

Dari hasil uji pada Tabel 1 terlihat bahwa dari 25 citra motif batik, yang mempunyai tingkat kemiripan (minimal 3 dari 5 mirip) terdapat 16 citra batik dan 9 citra motif batik (0 sampai 2 dari 5 mirip) yang terdeteksi tidak mirip dari total 25 citra. Tingkat kemiripan dalam persen (\%) dihitung menggunakan persamaan (1) dan (2) yaitu precision dan recall.

$$
\begin{aligned}
& \text { Precision }=\frac{16}{25} \times 100 \%=64 \% \\
& \text { Recall }=\frac{16}{125} \times 100 \%=12,8 \%
\end{aligned}
$$




\subsubsection{Pengujian menggunakan citra uji tersimpan}

Pada pengujian ini citra motif batik yang digunakan sebagai citra uji adalah citra motif batik yang sudah berbentuk berkas citra digital. Hasil uji kemiripan menggunakan citra uji tersimpan dapat dilihat pada Tabel 2 .

Tabel 2. Hasil Pengujian Menggunakan Citra Uji Tersimpan

\begin{tabular}{|c|c|c|c|}
\hline No & Citra Batik (Data Uji) & Hasil & Kemiripan Motif Batik \\
\hline 1 & Batik Ciptoning & 4 dari 5 mirip & Motif Kawung \\
\hline 2 & Batik Jogja & 4 dari 5 mirip & Motif Kawung \\
\hline 3 & Batik Tulis Madura & 3 dari 5 mirip & Motif Kawung \\
\hline 4 & Batik Truntum & 3 dari 5 mirip & Motif Nitik \\
\hline 5 & Batik Tiga Negeri & 5 dari 5 mirip & Motif Kawung \\
\hline 6 & Batik Tambal & 4 dari 5 mirip & Motif Kawung \\
\hline 7 & Batik Sulawesi Tengah & 5 dari 5 mirip & Morif Kawung \\
\hline 8 & Batik Sidomukti & 3 dari 5 mirip & Motif Nitik \\
\hline 9 & Batik Semarang Motif Tugu & 2 dari 5 mirip & Motif Nitik \\
\hline 10 & Batik Semarang & 3 dari 5 mirip & Motif Nitik \\
\hline 11 & Batik Sawat & 5 dari 5 mirip & Motif Nitik \\
\hline 12 & Batik Pekalongan & 3 dari 5 mirip & Motif Parang \\
\hline 13 & Batik Parang Rusak Barong & 3 dari 5 mirip & Motif Parang \\
\hline 14 & Batik Parang Kusumo & 2 dari 5 mirip & Motif Parang \\
\hline 15 & Batik Papua & 2 dari 5 mirip & Motif Nitik \\
\hline 16 & Batik Nitik Karawitan & 5 dari 5 mirip & Motif Parang \\
\hline 17 & Batik Melayu Tamban & 2 dari 5 mirip & Motif Parang \\
\hline 18 & Batik Melayu Keranggong & 3 dari 5 mirip & Motof Parang \\
\hline 19 & Batik Madura & 3 dari 5 mirip & Motif Parang \\
\hline 20 & Batik Liris & 5 dari 5 mirip & Motif Kawung \\
\hline 21 & Batik Kawung & 4 dari 5 mirip & Motif Parang \\
\hline 22 & Batik Indonesia & 5 dari 5 mirip & Motif Nitik \\
\hline 23 & Batik Gurda & 4 dari 5 mirip & Motif Kawung \\
\hline 24 & Batik Grompol 5 mirip & \\
\hline 25 & Batik Cuwiri & & \\
\hline
\end{tabular}

Dari hasil uji pada Tabel 2 terlihat bahwa dari 25 citra motif batik, yang mempunyai tingkat kemiripan (minimal 3 dari 5 mirip) terdapat 21 citra batik adalah mirip, dan 4 citra motif batik ( 0 sampai 2 dari 5 mirip) yang terdeteksi tidak mirip. Tingkat kemiripan dalam persen (\%) dihitung menggunakan Persamaan (1) dan (2) yaitu precision dan recall.

$$
\begin{aligned}
& \text { Precision }=\frac{21}{25} \times 100 \%=84 \% \\
& \text { Recall }=\frac{21}{125} \times 100 \%=16.8 \%
\end{aligned}
$$

\section{KESIMPULAN}

Pada kajian ini telah dilakukan pengkajian karakteristik metoda SIFT yang diterapkan pada aplikasi pencarian kemiripan bentuk motif batik. Aplikasi meTahapan utamanya adalah mengekstraksi fitur pada citra uji dan kumpulan citra pada direktori dengan ekstraksi fitur 
SIFT terlebih dahulu mendapatkan keypoint descriptor. Setelah dilakukan ekstraksi fitur pada citra langkah selanjutnya dapat menghitung similaritasnya dengan menggunakan nearest neighbor search untuk mengetahui bobot citra terendah dengan tingkat kemiripan yang tinggi.

Pengujian aplikasi dilakukan dengan 2 cara, pertama perolehan citra melalui kamera dimana, yang kedua adalah menggunakan citra motif batik yang sudah dalam bentuk digital yang ada di dalam database. Pengujian aplikasi dengan perolehan citra motif batik melalui kamera menghasilkan nilai precision $64 \%$ dan recall $12,8 \%$. Hal ini dikarenakan faktor saat pengambilan citra dan beberapa hal yang memungkinkan beerpengaruh pada tingkat kemiripan sehingga hasil pengujian terdapat ketidaksesuaian. Pengujian citra dengan menggunakan citra uji yang terdapat dalam database menghasilkan nilai precision $84 \%$ dan recall $16.8 \%$.

\section{DAFTAR RUJUKAN}

Agustin, Irvin, (2013), Analisis Dan Implementasi CBIR Menggunakan Penggabungan Variansi Ciri Warna Dan Bentuk, Skripsi

Almeida, Jurandy. (2009), SIFT applied to CBIR, Revista de Sistemas de Informacao da FSMA n. 4, pp. 41-48

Bharathi, K. (2017). Content Based Image Retrieval: An Overview of Architecture, Challenges and Issues, International Journal of Engineering Research in Computer Science and Engineering, Vol 4, Issue 12, $31-36$

Deselaers, Thomas. (2007). Features for Image Retrieval: An Experimental Comparison

Lestari, Nisaa Putri, (2016). Uji Recall and Precision Sistem Temu Kembali Informasi OPAC Perpustakaan ITS Surabaya, Skripsi

Lowe, David G. (2004). Distinctive Image Features from Scale-Invariant Keypoints, International Journal of Computer Vision

Pratama, Lingga Eka, (2014), Implementasi Algoritma SIFT (Scale Invariant Feature Transform) Untuk Melakukan Klasifikas Bahan Bakar Kendaraan Roda Empat Pada SPBU, Skripsi

Putri, Ghofinka, (2015), Analisis Dan Implementas Scale Invariant Feature Transform (SIFT) Pada Sistem Autentikasi Menggunakan Pembuluh Vena, e-Proceeding of Engineering, Vol.2, No.1, p.1353

Setiyawan, Agus, (2013), Pencocokan Citra Berbasis Scale Invariant Feature Transform (SIFT) Menggunakan Arc Cosinus, Skripsi 